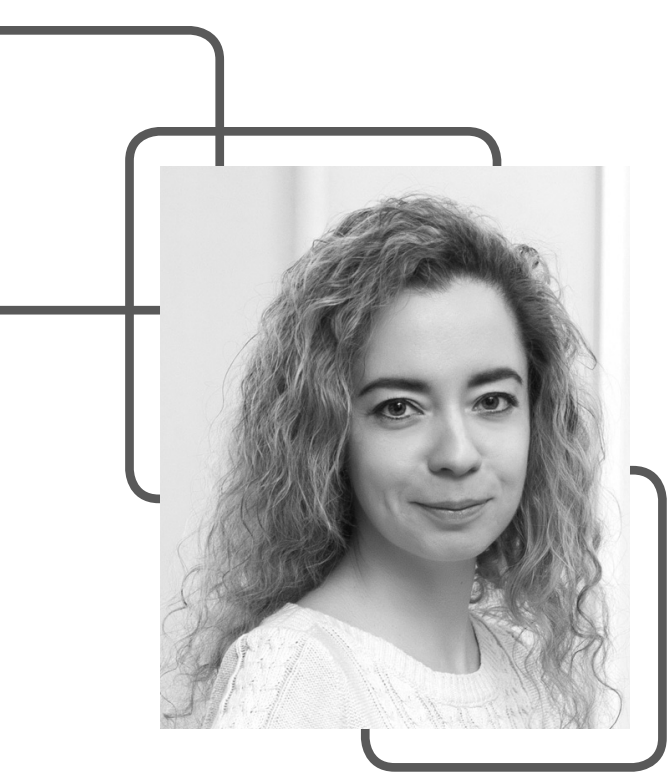

\title{
ОЦЕНКА ПРОДУКТИВНЫХ И ПРОИЗВОДСТВЕННЫХ ПОКАЗАТЕЛЕЙ КОРОВ РАЗНЫХ ПОРОД
}

\author{
А.С. Давыдова (фото) \\ научный сотрудник отдела инновационных разработок \\ в животноводстве

\section{Е.Г. Федосенко} \\ К.С.-Х.Н., заместитель директора по научной работе \\ ФГБНУ «Костромской научно-исследовательский институт \\ сельского хозяйства», с. Минское
}

В молочном скотоводстве Костромской области в последние годы наметилась негативная тенденция по сокращению численности крупного рогатого скота, а объёмы производства молока не покрывают потребности населения, что вызывает особую тревогу и требует поиска решения данной проблемы [1]. Наиболее эффективным способом увеличения объёмов производства является интенсификация отрасли, т.е. рост продуктивности скота и качественное улучшение существующих пород на основе совершенствования методов и форм племенной работы. В связи с этим нами была поставлена цель - изучить породный состав крупного рогатого скота в Костромской области и оценить эффективность использования коров разных пород [2, 3].

Dairy farming, breed, dairy productivity, duration of economic use

\section{Молочное скотоводство, порода, молочная продолюительность хозяйственного использования}

\section{Методика}

Материалом для исследований послужили данные мониторинга показателей развития агропромышленного комплекса Костромской области и результаты бонитировки крупного рогатого скота молочного направления продуктивности. Для достижения поставленной цели были использованы статистико-экономический и аналитический методы.

\section{Результаты исследований}

Порода в молочном скотоводстве является важнейшим фактором обеспечения высокого уровня продуктивности коров. Породный состав скота молочного направления продуктивности в хозяйствах Костромской области, по данным бонитировки, представлен на рисунке 1.

По данным департамента АПК Костромской области, в молочном скотоводстве региона ведётся работа по разведению четырёх пород молочного и молочно-мясного направлений продуктивности: костромской, чёрно-пёстрой, ярославской и айрширской. В 2018 году пробонитировано13582 голов крупного рогатого скота, что составляет от общего поголовья области всего лишь $36,6 \%$. По данным бонитировки, 44,4\% скота относится к костромской породе 


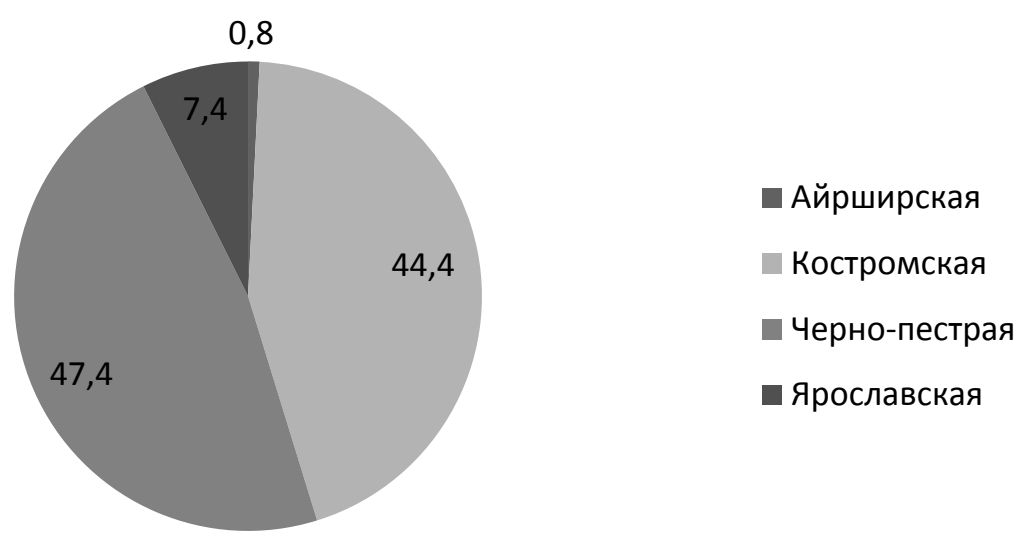

Рисунок 1 - Породный состав крупного рогатого скота молочного направления продуктивности в 2018 году, \%

крупного рогатого скота. Она является одной из лучших пород комбинированного направления продуктивности и превосходит другие породы по суммарной продукции молочного жира и белка за период хозяйственного использования.

В последние годы из-за высокой молочной продуктивности, интенсивности роста и развития, приспособленности к промышленной технологии производства молока широкое распространение получила чёрно-пёстрая порода скота. В 2018 году удельный вес чёрно-пёстрого скота в структуре поголовья Костромской области достиг 47,4\%. На долю ярославской породы приходится 7,4\% общего поголовья, а на долю айрширской породы - всего 0,8\%.

Показатели молочной продуктивности коров разных пород, разводимых в Костромской области, представлены в таблице 1.

Анализ показателей продуктивности коров показывает, что на протяжении трёх лет сохра-

Таблица 1 - Молочная продуктивность коров разных пород, разводимых в Костромской области

\begin{tabular}{|c|c|c|c|c|c|c|c|c|c|}
\hline \multirow{3}{*}{ Порода } & \multicolumn{9}{|c|}{ Год } \\
\hline & \multicolumn{3}{|c|}{2016} & \multicolumn{3}{|c|}{2017} & \multicolumn{3}{|c|}{2018} \\
\hline & удой, кг & МДж, \% & МДБ, \% & удой, кг & МДж, \% & МДБ, \% & удой, кг & МДж, \% & МДБ, \% \\
\hline Костромская & 5883 & 3,99 & 3,18 & 5753 & 4,04 & 3,20 & 5835 & 4,08 & 3,23 \\
\hline Чёрно-пёстрая & 6333 & 3,94 & 3,18 & 6405 & 3,97 & 3,20 & 6773 & 3,93 & 3,22 \\
\hline Ярославская & 5622 & 3,93 & 3,21 & 5816 & 3,88 & 3,12 & 6222 & 3,90 & 3,19 \\
\hline Айрширская & 4866 & 4,07 & 3,18 & 5172 & 4,17 & 3,35 & 6588 & 4,25 & 3,36 \\
\hline
\end{tabular}

няется тенденция роста удоев коров, за исключением костромской породы. В 2016-2018 гг. удой коров чёрно-пёстрой породы был выше на 7,7-30,1\%, 10,1-23,8 и 2,8-16,1\% соответственно, чем в среднем у других пород. По массовой доле жира и белка отличаются коровы костромской и айрширской пород. В 2018 г. наивысший удой молока в переводе на 4,0\%-ную жирность был получен от коров айрширской породы и находился на уровне 7000 кг, что больше на 345, 933 и 1048 кг, чем у коров чёрно-пёстрой, ярославской и костромской пород соответственно.

Эффективность молочного скотоводства во многом зависит от интенсивности сроков исполь- зования коров. При существующем экстенсивном методе выращивания молодняка крупного рогатого скота в регионе большое значение приобретает такой селекционный признак, как продолжительность хозяйственного использования животных $[4,5]$.

Распределение коров по числу отёлов в Костромской области представлено в таблице 2.

По данным таблицы 2, средняя продолжительность хозяйственного использования коров в регионе составляет 2,99 отёла. Следует отметить, что костромская порода крупного рогатого скота имеет некоторое преимущество по продолжительности хозяйственного использования, 
Таблица 2 - Распределение коров по числу отёлов в Костромской области в 2018 году

\begin{tabular}{|c|c|c|c|c|c|c|c|c|c|c|}
\hline \multirow{3}{*}{ Порода } & \multirow{3}{*}{$\begin{array}{c}\text { Кол-во } \\
\text { коров, } \\
\text { гол. }\end{array}$} & \multicolumn{8}{|c|}{ в том числе по отёлам } & \multirow{3}{*}{$\begin{array}{c}\text { Средний } \\
\text { возраст } \\
\text { в отёлах }\end{array}$} \\
\hline & & \multicolumn{2}{|r|}{1} & \multirow[b]{2}{*}{2} & \multirow[b]{2}{*}{3} & \multirow[b]{2}{*}{$4-5$} & \multirow[b]{2}{*}{$6-7$} & \multirow[b]{2}{*}{$8-9$} & \multirow[b]{2}{*}{$\begin{array}{c}10 \\
\text { и старше }\end{array}$} & \\
\hline & & всего & $\begin{array}{l}\text { в т.ч. с неза- } \\
\text { конченной } \\
\text { лактацией }\end{array}$ & & & & & & & \\
\hline Айрширская & 59 & 19 & 11 & 10 & 13 & 13 & 4 & - & - & 2,7 \\
\hline Костромская & 3588 & 918 & 528 & 731 & 591 & 776 & 440 & 106 & 26 & 3,28 \\
\hline Чёрно-пёстрая & 3497 & 911 & 538 & 968 & 829 & 508 & 171 & 83 & 27 & 2,74 \\
\hline Ярославская & 610 & 162 & 85 & 147 & 146 & 87 & 51 & 14 & 3 & 2,83 \\
\hline Итого & 7754 & 2010 & 1162 & 1856 & 1579 & 1384 & 666 & 203 & 56 & 2,99 \\
\hline
\end{tabular}

которая составляет 3,28 отёла. Коровы других пород по этому показателю уступали в среднем на 0,29-0,58 отёла.

Нами установлено, что в Костромской области затраты на выращивание и содержание коров начинают окупаться в возрасте 3,2 лактации. Поэтому необходимо стремиться к тому, чтобы от коров уже за первую лактацию получать высокие удои.

В ходе исследований нами также проведён анализ причин выбытия коров в хозяйствах Костромской области. Результаты представлены в таблице 3.
Анализ выбытия коров в хозяйствах региона показал, что основной причиной выбытия являются гинекологические заболевания и яловость - 21,7\% случаев выбытия. Особенно подвержены гинекологическим заболеваниям коровы костромской и ярославской пород, в меньшей степени - коровы чёрно-пёстрой породы и практически незначительно - коровы айрширской породы. Всего 7,3\% коров чёрно-пёстрой породы выбраковывается из стада по причине низкой продуктивности. Высокая доля выбывших коров по причине гинекологических заболеваний и яловости обусловлена несбалансиро-

Таблица 3 - Выбытие коров в хозяйствах Костромской области в 2018 г., \%

\begin{tabular}{|l|c|c|c|c|c|c|}
\hline \multirow{2}{*}{\multicolumn{1}{c|}{ Порода }} & \multicolumn{5}{|c|}{ Причины выбытия } \\
\cline { 2 - 7 } & $\begin{array}{c}\text { гинекология } \\
\text { и яловость }\end{array}$ & $\begin{array}{c}\text { низкая про- } \\
\text { дуктивность }\end{array}$ & $\begin{array}{c}\text { заболевания } \\
\text { вымени }\end{array}$ & $\begin{array}{c}\text { заболевания } \\
\text { конечностей }\end{array}$ & $\begin{array}{c}\text { травмы } \\
\text { иесчастные } \\
\text { случаи }\end{array}$ & $\begin{array}{c}\text { прочие } \\
\text { причины }\end{array}$ \\
\hline Костромская & 23,5 & 11,4 & 13,6 & 13,6 & 2,6 & 35,4 \\
\hline Чёрно-пёстрая & 19,8 & 7,3 & 24,1 & 15,4 & 4,8 & 28,6 \\
\hline Ярославская & 25,8 & 12,4 & 15,5 & 16,5 & 1,0 & 28,9 \\
\hline Айрширская & 5,0 & 30,0 & 20,0 & 15,0 & 15,0 & 15,0 \\
\hline В среднем по области & 21,7 & 9,7 & 18,8 & 14,6 & 3,7 & 31,5 \\
\hline
\end{tabular}

ванным кормлением и нарушением технологии содержания.

Высокопродуктивные коровы особенно восприимчивы к доильному оборудованию, но не во всех хозяйствах области оно современное. Отсюда коровы с высокой продуктивностью подвергаются заболеваниям вымени. Заболевания вымени чаще встречаются у коров чёрно-пёстрой и айрширской пород, чем у коров костромской и ярославской пород. Довольно высокий показатель выбытия коров всех пород связан с заболеванием конечностей и указывает на то, что животные содержатся в неудовлетворительных санитарногигиенических условиях. В частности, плохо убираются стойла, не всегда используется подстилка и современные дезинфицирующие средства.

В настоящее время молочное скотоводство в Костромской области является убыточной отраслью. В 2013-2017 гг. убыточность молочного скотоводства варьировала в пределах 16-27\% [6]. 


\section{Выводы}

Полученные в ходе исследования результаты дают основание сделать вывод, что имеющиеся на сельскохозяйственных предприятиях породы крупного рогатого скота, независимо от их породной принадлежности, могут быть эффективно использованы при производстве молока. Однако следует отметить, что повышение срока продуктивного использования коров и снижение уровня их выбраковки является одним из резервов повышения продуктивности стада и производства молока в целом. Для этого необходимо устранить погрешности в технологии содержания и кормления животных, в системе ветеринарно-санитарного обслуживания поголовья и селекционно-племенной работе с породами за счёт комплексного внедрения инновационных разработок в молочном скотоводстве Костромской области.

\section{Лumepamypa}

1. Мониторинг социально-экономического положения агропромышленного комплекса Костромской области за январь-декабрь 2016 года. Животноводство [Электронный ресурс]. - Режим доступа: http:// www.apkkostroma.ru.

2. Шендаков, А.И. Управление селекционно-генетическим процессом в животноводстве России: теория, практика и перспективы развития [Текст] / А.И. Шендаков // Биология в сельском хозяйстве. - 2014. № 1. - С. 2-18.

3. Импортозамещение в АПК России: проблемы и перспективы [Текст]: монография. - М.: ФГБНУ «Всероссийский НИИ экономики сельского хозяйства» (ФГБНУ ВНИИЭСХ), 2015. - 447 с.

4. Батанов, С. Влияние происхождения коров на продолжительность хозяйственного использования [Текст] / С. Батанов, Г. Березкина, Е. Шкарупа // Молочное и мясное скотоводство. - 2012. - № 3. - С. 19-21.

5. Кадиева, Т.А. Влияние различных факторов на продолжительность хозяйственного использования коров [Текст] / Т.А. Кадиева // Известия Горского государственного аграрного университета. - 2010. № 2. - С. 76-77.

6. Гвазава, Д.Г. Стратегия инновационного развития молочного скотоводства в Костромской области [Текст] / Д.Г. Гвазава, Л.А. Хомутова, Л.М. Исаева // Современные наукоемкие технологии. Региональное приложение. - 2019. - № 3. - С. 32-37.

\section{References}

1. Monitoring social'no-jekonomicheskogo polozhenija agropromyshlennogo kompleksa Kostromskoj oblasti za janvar'-dekabr' 2016 goda. Zhivotnovodstvo [Jelektronnyj resurs]. - Rezhim dostupa: http:// www. apkkostroma.ru.

2. Shendakov, A.I. Upravlenie selekcionno-geneticheskim processom v zhivotnovodstve Rossii: teorija, praktika i perspektivy razvitija [Tekst] / A.I. Shendakov // Biologija v sel'skom hozjajstve. - 2014. - № 1. - S. 2-18.

3. Importozameshhenie v APK Rossii: problemy i perspektivy [Tekst]: monografija. - M.: FGBNU «Vserossijskij NII jekonomiki sel'skogo hozjajstva» (FGBNU VNIIJeSH), 2015. - $447 \mathrm{~s}$.

4. Batanov, S. Vlijanie proishozhdenija korov na prodolzhitel'nost' hozjajstvennogo ispol'zovanija [Tekst] / S. Batanov, G. Berezkina, E. Shkarupa // Molochnoe i mjasnoe skotovodstvo. - 2012. - № 3. - S. 19-21.

5. Kadieva, T.A. Vlijanie razlichnyh faktorov na prodolzhitel'nost' hozjajstvennogo ispol'zovanija korov [Tekst] / T.A. Kadieva // Izvestija Gorskogo gosudarstvennogo agrarnogo universiteta. - 2010. - № 2. - S. 76-77.

6. Gvazava, D.G. Strategija innovacionnogo razvitija molochnogo skotovodstva v Kostromskoj oblasti [Tekst] / D.G. Gvazava, L.A. Khomutova, L.M. Isaeva // Sovremennye naukoemkie tehnologii. Regional'noe prilozhenie. 2019. - № 3. - S. 32-37. 